indicated in brackets: Fellowships: Dr. J. M. Lambert, lecturer in botany, Westfield College, University of London (ecological investigations into the vegetation in the region of the Norfolk Broads); Mr. D. B. Scott, lecturer in mathematics, King's College, University of London (applications of modern abstract algebra to algebraic geometry); Prof. A. J. B. Wace, professor of classics and archæology, Farouk I University, Alexandria (Mycenæ and the civilization of the Agean Bronze Age). Research Grants : Dr. C. W. Dixon, lecturer and chief assistant, Department of Preventive Medicine and Public Health, University of Leeds (epidemiology of smallpox and control of variola minor); Dr. V. Elwin, of the Tribal Art Research Unit, India (tribal art in eastcentral India); B. H. Farmer, St. John's College, Cambridge (pioneer settlement in Ceylon); E. Green, general secretary, Workers' Education Association (present-day apathy to adult education); Dr. J. H. G. Lebon, lately professor of geography, University of Ceylon (origins and development of rural settlement in Scotland); Dr. H. M. Muir-Wood, a principal scientific officer, Department of Geology, British Museum (Natural History) (morphology and classification of Brachiopoda); Dr. D. M. Steven, lecturer in zoology, University of Edinburgh (species relationships of British voles); Mr. J. Walton, education officer, Basutoland (native housing in Southern Rhodesia); Mr. J. W. Wright, inspector of surveys, Sudan Government (hydrology of the Riber Sobat and its relation with the White Nile). Information relating to Leverhulme awards can be obtained from the Secretary, Leverhulme Research Fellowships, 7 Bedford Row, London, W.C.I.

\section{International Physiological Congress}

The Eighteenth International Physiological Congress will be held at Copenhagen during August 15-18. A large part of the programme has been reserved for 'general discussions', which will deal with selected physiological problems. These include: salt and water excretion; thermodynamics of muscle, hormonal control of fat metabolism ; transport of substances across cell membranes; physiology of the retina, principles of spinal cord activity ; and cardiac output in man. As on previous occasions, it has been necessary to arrange the scientific meetings in several sections which will proceed simultaneously. The Congress is to be followed by a meeting of the Scandinavian Pharmacological Society on August 19, at which the properties of adrenaline, nor-adrenaline and related substances will be discussed.

\section{Announcements}

Srr John ANDerson has been elected president for the coming year of the British Standards Institution in succession to Sir William Larke.

THe University of Manchester has conferred the honorary degree of M.Se. on Dr. W. H. Brindley for industrial and public services. Dr. Brindley, who is librarian of Hardman and Holden, Ltd., Manchester, has been honorary secretary and treasurer of the Manchester Section of the Society of Chemical Industry since 1934, and honorary librarian of the Manchester Literary and Philosophical Society since 1940.

A JapaNese National Institute of Genetics has recently been established at Misima under the directorship of Dr. Kan Oguma. At present it comprises three departments: (1) Phenogenetic; (2)
Cytogenetic ; (3) Physiogenetic. It is hoped to cover all branches of genetics, pure and applied, dealing with human, animal and plant material.

The Second Biennial Congress of the International Union of Leather Chemists' Societies will be held in London during September 10-13, 1951, at Regent Street Polytechnic (Portland Hall Annexe), Great Portland Street, London, W.1, at the invitation of the Society of Leather Trades' Chemists. Further details will be announced in due course.

THE Electronics Section of the Scientific Instrument Manufacturers' Association is holding its annual exhibition and symposium at the Examination Hall, Queen Square, London, W.C.1, during September 5-8. As in previous years, a series of technical papers will be read by specialist scientific workers and engineers. Also, there will be a comprehensive display of the latest types of British scientific and electronic instruments. Entrance to the symposium itself will be by ticket of admission (covering also the exhibition), obtainable on application to the Secretary of the Scientific Instrument Manufacturers' Association, 17 Princes Gate, London, S.W.7.

THe Commonwealth Scientific and Industrial Research Organisation has decided to publish a new journal, Australian Journal of Marine and Freshwater Research, as a medium for the publication of research papers on the results of original investigations on sea, estuarine, and freshwater fisheries and cognate subjects. It will not appear regularly, but as material becomes available. However, it is expected that two issues of the Journal will be published each year ; each issue will cost 7s. 6d. per copy. Correspondence should be addressed to the Secretary, Commonwealth Scientific and Industrial Research Organisation, 314 Albert Street, East Melbourne, C.2.

DR. F. S. Stewari, assistant and lecturer in bacteriology in Trinity College (University of Dublin), has been appointed to the chair of bacteriology and preventive medicine in the College, in succession to Prof. J. W. Bigger, who retires at the end of September. Dr. Stewart, who is thirty-five, was educated at Wesley College and at Trinity College, Dublin. He distinguished himself first in philosophy, turning later to medical studies. He has published papers on $R h$ immunization and on the antigenic modification of red cells by periodate.

The McCharles Prize of 1,000 dollars, which is awarded periodically by the Canadian Institute of Mining and Metallurgy "for the discovery or improved development of new life-saving devices in the power and light industry, or for any notable achievement in scientific research in any useful practical line", has recently been presented to Christian Lapointe, of the Radioactivity Division, Mines Branch, Ottawa. The award, together with a medal, has been made to Dr. Lapointe in recognition of his researches on the measurement, concentration and extraction of uranium from its ores. Notable among the inventions originating from these researches is the Lapointe picker, an ore-picking belt controlled by Geiger counters, by means of which high-grade pitchblende concentrates are automatically prepared from the uranium ores mined at Great Bear Lake.

ERratum. In Nature of July 1, p. 17, column 2, paragraph 2, for "International Council of Biological Unions" read "International Council of Scientific Unions". 